\title{
Prion Protein Helix1 Promotes Aggregation but Is Not Converted into $\beta$-Sheet ${ }^{*}$
}

Received for publication, May 30, 2006, and in revised form, July 24, 2006 Published, JBC Papers in Press, July 26, 2006, DOI 10.1074/jbc. M605141200

\author{
Jens Watzlawik ${ }^{\ddagger}$, Lukasz Skora ${ }^{\S 1}$, Dieter Frense", Christian Griesinger ${ }^{\S}$, Markus Zweckstetter ${ }^{\S \|}$, \\ Walter J. Schulz-Schaeffer ${ }^{\ddagger}$, and Michael L. Kramer ${ }^{\ddagger 2}$ \\ From the ${ }^{\ddagger}$ Prion and Dementia Research Unit, Institute of Neuropathology, University of Goettingen, 37075 Goettingen, Germany, \\ ${ }^{\S}$ NMR Based Structural Biology, Max Planck Institute for Biophysical Chemistry, 37077 Goettingen, Germany, Deutsche \\ Forschungsgemeinschaft (DFG) Research Center for the Molecular Physiology of the Brain, 37075 Goettingen, Germany, and \\ "Institute for Bioprocess and Analytical Measurement Techniques, 37308 Heiligenstadt, Germany
}

Prion diseases are caused by the aggregation of the native $\alpha$-helical prion protein $\operatorname{PrP}^{\mathrm{C}}$ into its pathological $\beta$-sheet-rich isoform $\operatorname{PrP}^{\mathrm{Sc}}$. In current models of $\operatorname{PrP}^{\mathrm{Sc}}$, helix 1 is assumed to be preferentially converted into $\beta$-sheet during aggregation of $\operatorname{PrP}^{\mathrm{C}}$. This was supported by the NMR structure of $\operatorname{PrP}^{\mathrm{C}}$ since, in contrast to the isolated helix1, helix 2 and helix 3 are connected by a small loop and are additionally stabilized by an interhelical disulfide bond. However, helix1 is extremely hydrophilic and has a high helix propensity. This prompted us to investigate the role of helix1 in prion aggregation using hum $\mathrm{PrP}_{23-159}$ including helix1 (144-156) compared with the C-terminal-truncated isoform hum $\operatorname{PrP}_{23-144}$ corresponding to the pathological human stop mutations Q160Stop and Y145Stop, respectively. Most unexpectedly, hum $\operatorname{PrP}_{23-159}$ aggregated significantly faster compared with the truncated fragment hum $\operatorname{PrP}_{23-144}$, clearly demonstrating that helix 1 is involved in the aggregation process. However, helix 1 is not resistant to digestion with proteinase $\mathrm{K}$ in fibrillar hum $\mathrm{PrP}_{23-159}$, suggesting that helix1 is not converted to $\boldsymbol{\beta}$-sheet. This is confirmed by Fourier transformation infrared spectroscopy since there is almost no difference in $\beta$-sheet content of humPrP ${ }_{23-159}$ fibrils compared with hum $\operatorname{PrP}_{23-144}$. In conclusion, we provide strong direct evidence that in contrast to earlier assumptions helix1 is not converted into $\beta$-sheet during aggregation of $\operatorname{PrP}^{\mathrm{C}}$ to $\operatorname{PrP}^{\mathrm{Sc}}$.

Prion diseases are caused by the pathological deposition of the prion protein in its aggregated form. In sporadic Creutzfeldt-Jakob disease (CJD) ${ }^{3}$ the endogenous prion protein aggregates spontaneously. In contrast, mutations within the prion protein gene cause familial CJDs and Gerstmann-SträusslerScheinker syndrome (GSS) including two stop mutations

* This research was supported in part by the Max Planck Society (to C. G.), by the European Union (UPMAN) through Deutsche Forschungsgemeinschaft Emmy Noether Fellowship ZW 71/1-5 (to M. Z.), and by the VolkswagenStiftung (ZN1294) (to W. J. S.-S.). The costs of publication of this article were defrayed in part by the payment of page charges. This article must therefore be hereby marked "advertisement" in accordance with 18 U.S.C. Section 1734 solely to indicate this fact.

1 Recipient of Marie Curie Fellowship MEST-CT-2004-504193.

${ }^{2}$ To whom correspondence should be addressed. E-mail: mkramer@med. uni-goettingen.de.

${ }^{3}$ The abbreviations used are: CJD, Creutzfeldt-Jakob disease; PrP, prion protein; GSS, Gerstmann-Sträussler-Scheinker syndrome; BisTris, 2-[bis(2-hydroxyethyl)amino]-2-(hydroxymethyl)propane-1,3-diol; PK, proteinase K; FTIR, Fourier transformation infrared spectroscopy.
Y145Stop and Q160Stop with a GSS-like phenotype. The most important aspect is the transmission of prion protein aggregates from one individual or species to another, causing prion diseases such as scrapie in sheep, bovine spongiform encephalopathy (BSE) in cattle, chronic wasting disease in deer, or variant CJD in humans. So far all experimental data strongly support the hypothesis that only one protein, the prion protein, is responsible for this virus-like infectivity (1).

Native prion protein $\left(\operatorname{PrP}^{C}\right)$ is attached to the extracellular plasma membrane surface by a glycosylphosphatidylinositol lipid anchor and undergoes endocytosis. In vivo endocytosis was shown to be essential for conversion of $\mathrm{PrP}^{\mathrm{C}}$ into the pathological and infectious $\mathrm{PrP}^{\mathrm{Sc}}$. This suggested that changes in $\mathrm{pH}$ are involved in the conversion process. Indeed, a $\beta$-sheet-rich oligomeric intermediate $(\beta-\mathrm{PrP})$ was identified at acidic $\mathrm{pH}$ under denaturing conditions $(2,3)$. Longer incubation resulted in fibril formation $(4,5)$.

Many efforts have been made to elucidate the molecular mechanisms of prion protein aggregation. Investigation of known mutations in prion protein associated with GSS and CJD showed only partially a thermodynamic destabilization of the ground states $(6,7)$. Therefore, a thermodynamic destabilization of $\operatorname{PrP}^{C}$ was excluded as a general mechanism for $\operatorname{PrP}^{\mathrm{Sc}}$ formation. The oligomeric $\beta$-sheet-rich $\beta$-PrP was even more stable than $\operatorname{PrP}^{C}(8)$. However, there was a high energetic barrier between the $\operatorname{PrP}^{C}$ and the $\beta$-PrP form, which clearly demonstrates a kinetic control of the conversion process (8). This barrier was shown to be significantly dependent on $\mathrm{pH}(9)$.

The N-terminal segment of $\mathrm{PrP}^{\mathrm{C}}$ from amino acid 23 to 126 is largely unstructured (10). Two pathological GSS-like mutations, Y145Stop and Q160Stop, result in C-terminal truncated isoforms. The truncation occurs just after the central region from amino acid 90 to 145 , which was shown to be converted into $\beta$-sheet $(11,12)$. In contrast to the full-length prion protein, the Y145Stop mutant was shown to aggregate under native nondenaturing rather neutral $\mathrm{pH}$ conditions (13). Working under non-denaturing conditions appears promising since for the first time an in vitro model for the species barrier was established solely by using recombinant $\operatorname{PrP}_{23-144}(12,14)$. The present investigation aimed at clarifying the role of helix1 in the conversion process of the prion protein under native conditions.

During conversion to $\mathrm{PrP}^{\mathrm{Sc}}$ a significant part of the prion protein adopts $\beta$-sheet structure (15). However, the role of helix1 (16) in this process is still unclear. Originally, helix1 was thought to be 
converted into $\beta$-sheet $(16,17)$. Using the GSS-like Q160Stop mutant prion protein ( $\left.h u m \operatorname{PrP}_{23-159}\right)$ including helix1 (amino acid 144-156), we demonstrate here for the first time that the helix1 is not converted to $\beta$-sheet. Quite unexpectedly, we observed that hum $\operatorname{PrP}_{23-159}$ aggregated significantly faster compared with hum $\mathrm{PrP}_{23-144}$, suggesting an unusual role of the polar helix1 in the conversion process.

\section{EXPERIMENTAL PROCEDURES}

Plasmid Construction and Protein Purification-The open reading frame coding for hum $\operatorname{PrP}(23-231)$ was amplified from human tissue and cloned into the plasmid pBluescript II SK $(+)$ (Stratagene). The open reading frames for humPrP (23-144) and humPrP (23-159) were amplified from the plasmid pBluescript II SK(+)/humPrP (23-231) using the oligonucleotide primers 23MSup (5'-CGACGGTAAAGCTTACATATGAGCAAGAAGCGCCCGAAG-3') and 145do (5' -ACGATAGTAGTCGACCTATTAGTCACTGCCGAAATG-3') or 160do (5' -GGGCCTGTAGTCGACTTAGTTGGGGTAACGGTG$\left.3^{\prime}\right)$. The resulting open reading frames were cloned into the plasmid pET27b (Novagen) via the NdeI and SalI restriction sites. Full-length prion protein and stop mutants were expressed in BL21(DE3) and purified as described previously (18).

CD Spectroscopy -Far UV circular dichroism spectra were recorded on a CD6 (Jobin Yvon) in 25 mm sodium acetate, $\mathrm{pH}$ 6.0 , at $25^{\circ} \mathrm{C}$ using a quartz cell with a path length of $0.1 \mathrm{~mm}$. Protein concentrations were $80 \mu \mathrm{M}$. All spectra were corrected for absorbance of buffer.

Thioflavin T Fluorescence Assay-Mutant proteins were directly dissolved in water, and the $\mathrm{pH}$ was adjusted to 6.5 . The reaction was started by transferring protein solutions to a buffer ( $25 \mathrm{~mm}$ acetate and $25 \mathrm{~mm}$ phosphate at $\mathrm{pH} 6.5$ ) and incubated at $25^{\circ} \mathrm{C}$. In seeding experiments $1 \%(\mathrm{w} / \mathrm{w})$ sonicated seed of fibrillar hum $\mathrm{PrP}_{23-159}$, hum $\operatorname{PrP}_{23-144}$, or hum $\mathrm{PrP}_{106-126}$ was added to $200 \mu \mathrm{M}$ protein.

Fibril formation was monitored by thioflavin $\mathrm{T}$ fluorescence at $492 \mathrm{~nm}$ with excitation at $450 \mathrm{~nm}$. At the corresponding times aliquots were withdrawn and diluted to a final monomer concentration of $6 \mu \mathrm{M}$ with $50 \mathrm{~mm}$ BisTris/HCl, $\mathrm{pH}$ 6.7. After the addition of $10 \mu \mathrm{M}$ thioflavin $\mathrm{T}$, samples were incubated for $5 \mathrm{~min}$ at $30^{\circ} \mathrm{C}$ before reading the fluorescence.

The data of kinetics were fitted according to Equation 1 using SigmaPlot 8.0, where $Y_{0}$ corresponds to the basic fluorescence, $a$ is the amplitude of the reaction, $b$ is equivalent to velocity constant, and $x_{0}$ is the halftime of aggregation.

$$
F_{\text {rel }}=Y_{0}+\frac{a}{\left\{1+\exp \left(-\frac{x-x_{0}}{b}\right)\right\}}
$$

For seeding of hum $\operatorname{PrP}_{23-144}$ showing a prephase aggregation curves were fitted according to Equation 2.

$$
F_{\text {rel }}=Y_{0}+\frac{a}{\left\{1+\exp \left(-\frac{x-x_{0}}{b}\right)\right\}}+\frac{c}{\left\{1+\exp \left(-\frac{x-z_{0}}{d}\right)\right\}}
$$

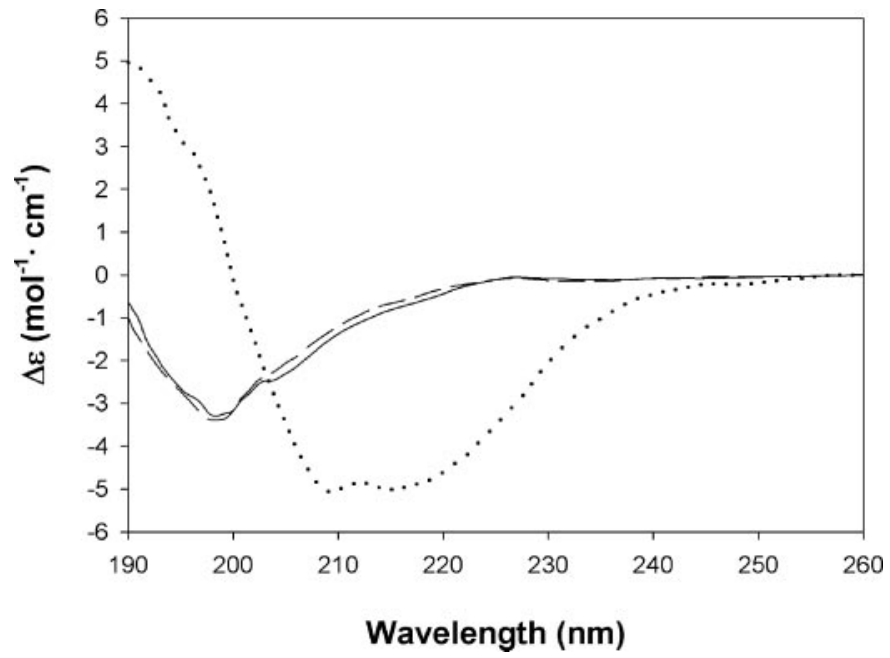

FIGURE 1. Native prion stop mutants are largely random coil. CD spectroscopy of humPrP $23-159$ (solid line) and humPrP $23-144$ (dashed line) in $25 \mathrm{~mm}$ sodium acetate, $\mathrm{pH} 6.0$, shows almost identical spectra typical for the random coil, which are in contrast to $\alpha$-helical full-length prion protein humPrP $23-231$ (dotted line). All spectra were recorded at protein concentrations of $80 \mu \mathrm{M}$.

Proteinase K Digestion-Prion fibrils were digested in $50 \mathrm{~mm}$ Tris/HCl, pH 8.0, $100 \mathrm{~mm} \mathrm{NaCl}, 0.1 \%$ Brij, 0.5\% Nonidet P40, $0.5 \%$ deoxycholate with proteinase $\mathrm{K}$ at $37^{\circ} \mathrm{C}$ for $1 \mathrm{~h}$ with protein to proteinase $\mathrm{K}(\mathrm{PK})$ ratios of $104: 1(50 \mu \mathrm{g} / \mathrm{ml} \mathrm{PK})$ and 52:1 ratio $(100 \mu \mathrm{g} / \mathrm{ml} \mathrm{PK})$, respectively. The digestion was stopped with $1 \mathrm{~mm}$ phenylmethylsulfonyl fluoride, boiled for $10 \mathrm{~min}$ in SDS sample buffer, and analyzed on a $17.5 \%$ SDS- polyacrylamide gel as described (19). For Western blot analysis $6 \mathrm{H} 4$ $(1: 10,000)$ and $1 \mathrm{E} 4(1: 10,000)$ were used, and immunoreactivity was detected by chemiluminescence. Edman sequencing was performed using a Procise cLC protein sequencer (Applied Biosystems) according to the manufacturer's standard protocols.

Fourier Transformation Infrared Spectroscopy (FTIR)_FTIR measurements were performed on a Nicolet 6700 (Thermo Electron Corp.) constantly purged with dried air. All buffers and mutant proteins were exchanged three times with $\mathrm{D}_{2} \mathrm{O}$ by lyophilization. Aggregation was performed at a pD of $6.5 \mathrm{using}$ $25 \mathrm{~mm}$ phosphate and $25 \mathrm{~mm}$ acetic acid as buffer. For measurements, $\mathrm{CaF}_{2}$ windows with a $50-\mu \mathrm{m}$ Teflon spacer were used. In total 256 spectra were averaged with a resolution of 2 $\mathrm{cm}^{-1}$. Spectra were corrected for buffer absorbance.

Peak fitting was done with PeakFit v. 4 (SPSS Inc.) using the option of automatic peak detection by the second derivative method. For fitting the implemented real Voigt function was used considering both Gaussian and Lorentzian peak broadening.

Electron Microscope Analysis of Aggregates-After termination of the aggregation aliquots of $10 \mu \mathrm{l}$ were placed on a carbon-coated copper grid and stained with $2 \%$ aqueous (w/v) uranyl acetate for $5 \mathrm{~min}$. After washing and drying, protein aggregates on the grids were visualized using a Zeiss $10 \mathrm{~B}$ electron microscope operating at $60 \mathrm{kV}$.

NMR Analysis of humPrP ${ }_{23-159}-$ hum $\operatorname{PrP}_{23-159}$ was ${ }^{13} \mathrm{C}-$ and ${ }^{15} \mathrm{~N}$-labeled in $\mathrm{M} 9$ minimal medium according to standard procedures. The NMR sample contained $1 \mathrm{~mm}^{13} \mathrm{C},{ }^{15} \mathrm{~N}$-labeled hum $\operatorname{PrP}_{23-159}$ in $93 \% \mathrm{H}_{2} \mathrm{O}, 7 \% \mathrm{D}_{2} \mathrm{O}, 10 \mathrm{~mm}$ sodium acetate buffer, $\mathrm{pH} 4.5$ and 6.5. All spectra were acquired at $293 \mathrm{~K}$ on a 
A

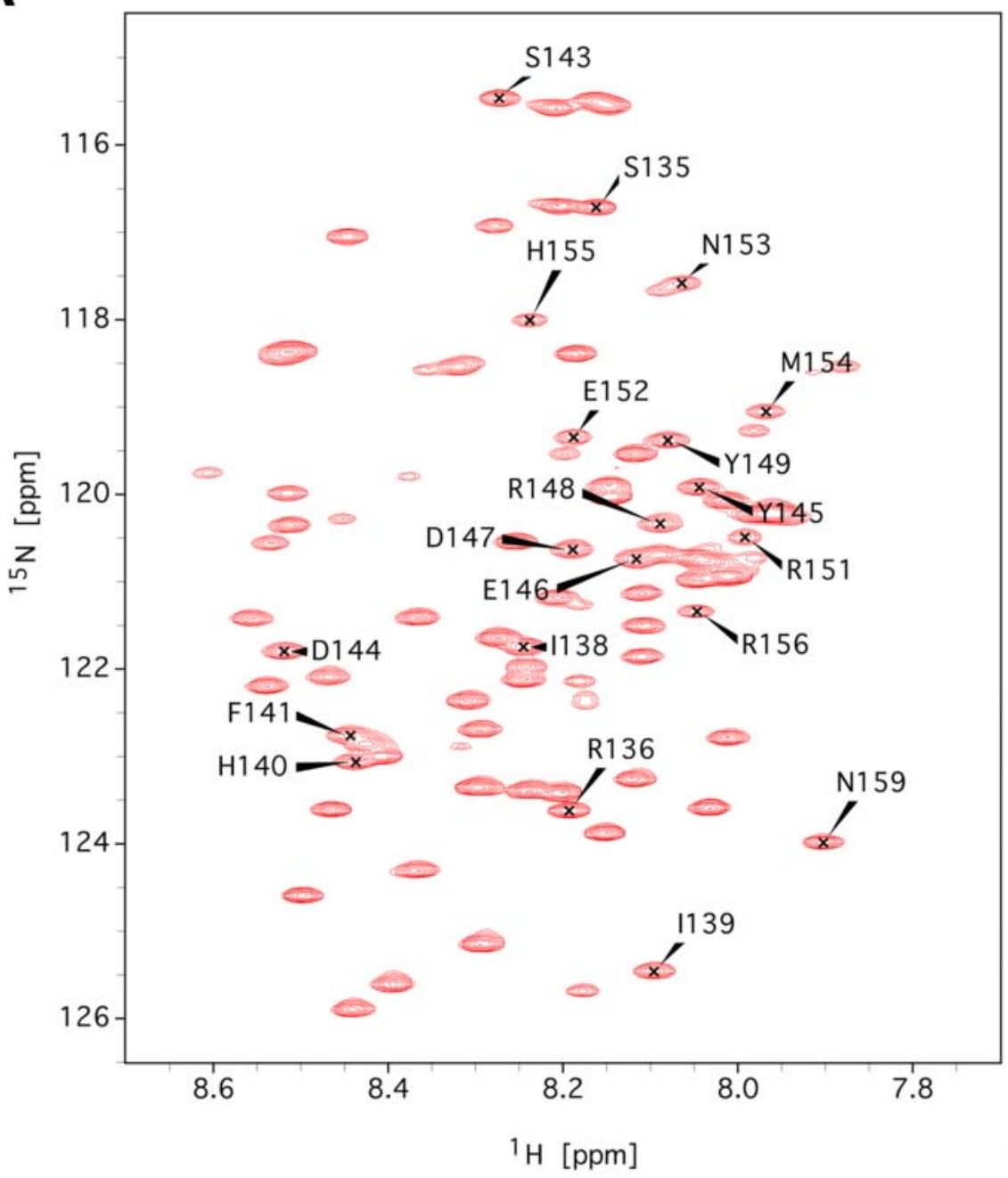

B

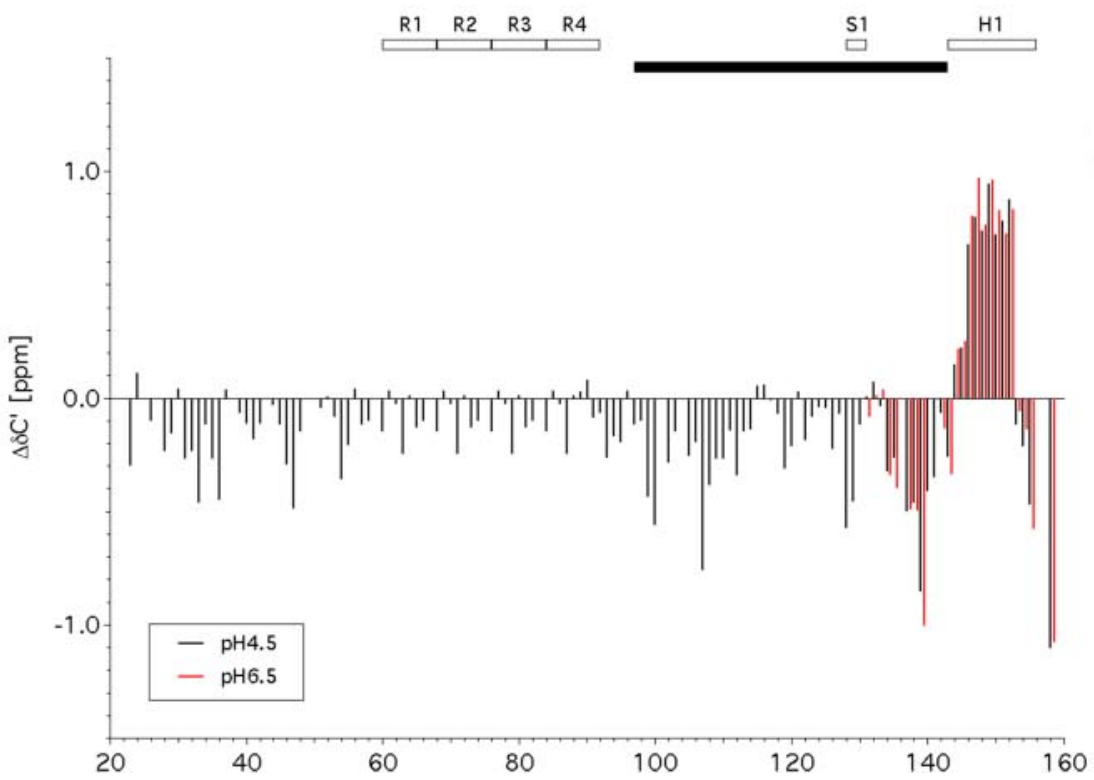

FIGURE 2. Detection of helix1 in humPrP ${ }_{23-159}$ by NMR spectroscopy. $A,{ }^{1} H_{1}{ }^{15} \mathrm{~N}$ HSQC spectrum of humPrP $23-159$ at $\mathrm{pH}$ 4.5. Assignment for residues $135-159$ is indicated by arrows. $B$, averaged ${ }^{13} \mathrm{C}$ secondary chemical shifts of humPrP $23-159$ at 4.5 (black) and 6.5 (red). The average shifts were calculated as $[\Delta \delta(C \alpha)+$ $\left.\Delta \delta\left(C^{\prime}\right)\right] / 2$. Open bars indicate the positions of octarepeats (R1-R4), $\beta$-strand I (S1), and helix I (H1); the filled bar marks a region known to be converted into $\beta$-sheet in $\operatorname{PrP}^{\mathrm{Sc}}(11)$.
Bruker Avance $900 \mathrm{MHz}$ spectrometer equipped with a cryo probe head. NMR data were processed and analyzed using nmrPipe (20) and Sparky. Three-dimensional HACANNH, HNCO, and HNN experiments (21) were collected to obtain sequence-specific backbone assignment. Secondary chemical shifts were calculated as differences between the measured $\mathrm{C} \alpha / \mathrm{C}^{\prime}$ shifts and empirical random coil values at pH 3.0 (22). Random coil values for prolines and aspartates were taken from Wishart and Sykes (23).

\section{RESULTS}

Structure of the Native Q160Stop Mutant-Before starting the aggregation experiments, both mutant proteins were subjected to capillary electrophoresis, which was shown previously to detect oligomers early in the aggregation process (24). The electropherograms showed only one single peak each, which clearly demonstrated their monomeric state (data not shown).

Because hum $\operatorname{PrP}_{23-159}$ includes the helix1, we examined whether it was detectable using $\mathrm{CD}$ spectroscopy (Fig. 1). However, the CD spectrum of hum $\mathrm{PrP}_{23-159}$ is almost identical to that of hum $\operatorname{PrP}_{23-144}$, which corresponds to a spectrum of random coil, as shown previously for hum $\operatorname{PrP}_{23-144}$ (25). It appeared that the fraction of amino acids in hum $\mathrm{PrP}_{23-159}$ corresponding to helix1 is too low to be detected by any analytical technique that determines the sequence-independent average conformation, such as $\mathrm{CD}$ spectroscopy.

Therefore, the structure of the helix1 segment in hum $\operatorname{PrP}_{23-159}$ was analyzed by NMR spectroscopy. NMR chemical shifts, especially of $\mathrm{C} \alpha$ and $\mathrm{C}^{\prime}$ atoms, are a very sensitive indicator for sequence dependent secondary structure both in globular and unfolded proteins (26). These shifts show small but distinct deviations from random coil values. The deviations, called secondary chemical shifts, are shown in Fig. 2. A continuous stretch of positive secondary chemical shifts was 

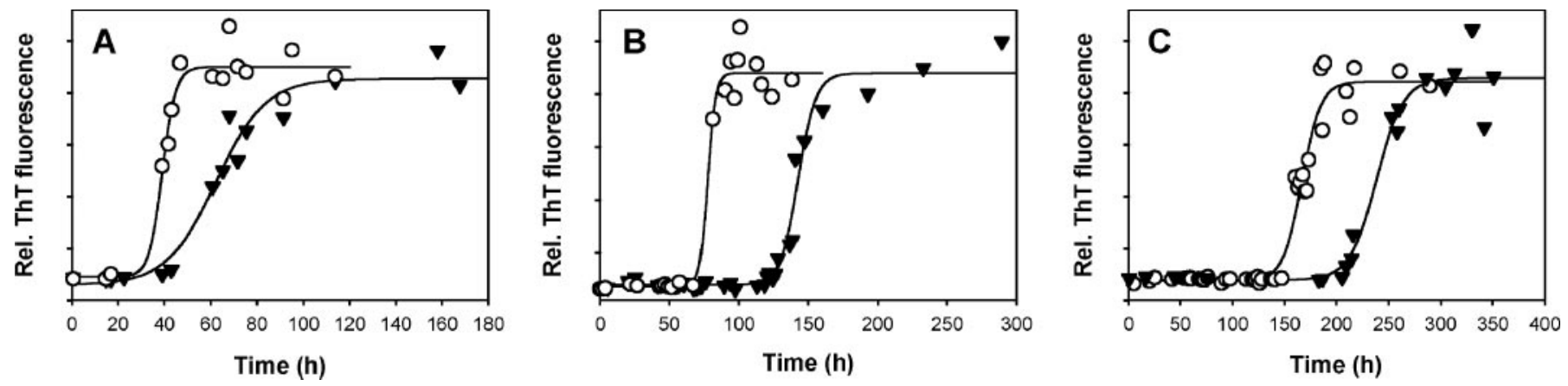

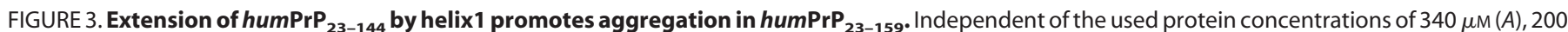

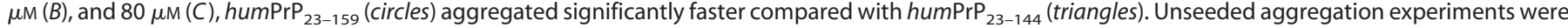

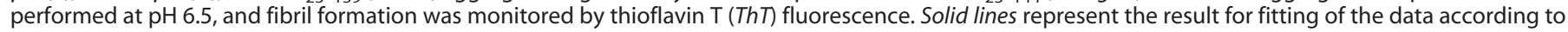
Equation 1.

found for residues 144-154, indicative of helical structure. Most other residues show slightly negative secondary chemical shifts, reporting on a propensity to form $\beta$-structure. Interestingly, the highest propensity to form $\beta$-structure is present for residues $98-143$, a region known to be converted into $\beta$-sheet on $\mathrm{PrP}^{\mathrm{Sc}}$ formation (11). In particular Ile-139, one of two residues that are critical for the conformational properties of hum $\mathrm{PrP}_{23-144}$ fibrils (14), has the most negative secondary chemical shift, i.e. the strongest propensity for $\beta$-structure.

NMR secondary chemical shifts clearly demonstrate the presence of a significantly populated helix 1 in hum $\operatorname{PrP}_{23-159}$. Comparison of average shift magnitudes for the helix1 region observed in hum $\operatorname{PrP}_{23-159}$ and hum $\mathrm{PrP}_{23-230}$ (Biological Magnetic Resonance Data Bank entry 4402) revealed an $\alpha$-helical content of $33 \%$ in hum $\operatorname{PrP}_{23-159}$ with respect to the full-length protein (data not shown). As expected from the data on hum $\mathrm{PrP}_{140-158}$ (27), helix1 is present in hum $\mathrm{PrP}_{23-159}$ at $\mathrm{pH}$ 4.5 as well as pH 6.5 (Fig. 2B).

humPrP $23-159$ Aggregates Faster than humPrP ${ }_{23-144}$-To obtain direct insight into the role of the helix1 during prion protein aggregation, we investigated the aggregation kinetics of hum $\operatorname{PrP}_{23-159}$ compared with humPrP $23-144$. We demonstrate here for the first time that hum $\operatorname{PrP}_{23-159}$ readily aggregates under physiological non-denaturing conditions (Fig. 3). However, in contrast to the Y145Stop mutant, hum $\operatorname{PrP}_{23-159}$ is extended C-terminally by the helix1 segment. Apart from the presence of helix in the helix1 segment of hum $\operatorname{PrP}_{23-159}$, this segment is still rather polar, including $50 \%$ charged residues. Therefore, we expected this to significantly increase the lag phase with respect to hum $\operatorname{PrP}_{23-144}$. In addition, full-length prion protein has not yet been shown to aggregate under these conditions. Most unexpectedly, we observed the opposite; independent from the protein concentration, hum $\operatorname{PrP}_{23-159}$ aggregated significantly faster compared with hum $\operatorname{PrP}_{23-144}$, which clearly demonstrates an aggregation-promoting effect of helix1. From triple experiments, the average aggregation halftime of hum $\operatorname{PrP}_{23-159}$ at $340 \mu \mathrm{M}$ was $39 \mathrm{~h}$ compared with $67 \mathrm{~h}$ for the Y145Stop mutant. At 200 and $80 \mu \mathrm{M}$, the aggregation halftimes were 68 and $171 \mathrm{~h}$ for hum $\operatorname{PrP}_{23-159}$ or $138 \mathrm{~h}$ and $242 \mathrm{~h}$ for hum $\operatorname{PrP}_{23-144}$.

Electron microscopy revealed that hum $\operatorname{PrP}_{23-159}$, like hum $\operatorname{PrP}_{23-144}$, indeed forms fibrils (Fig. 4). However, no significant differences were observed for both mutants. Both form a

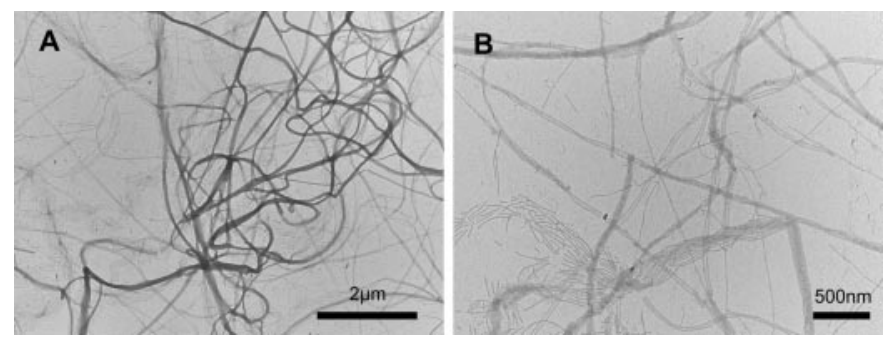

FIGURE 4. humPrP ${ }_{23-159}$ forms highly bundled fibrils. Electron microscopy reveals that humPrP $23-159(A)$, as humPrP $23-144(B)$, forms highly bundled fibrils. They are branched with average diameters ranging from 50 to $70 \mathrm{~nm}$ and extend over several micrometers. Fibrils were taken from an unseeded preparation of $200 \mu \mathrm{m}$ protein after $100 \mathrm{~h}$ at pH 6.5 (see Fig. 3). The average fibril diameter of both mutants is in the range from 8 to $12 \mathrm{~nm}$. They are made up by two protofibrils.

fiber network composed of highly bundled fibrils with average diameters ranging from 50 to $70 \mathrm{~nm}$ but maximal up to $350 \mathrm{~nm}$. These bundles extend over several micrometers and are formed by fibrils with diameters from $8-12 \mathrm{~nm}$ made up of two protofibrils. This is identical to the results shown for hum $\mathrm{PrP}_{23-144}$ (13).

Seeded Aggregation of humPrP ${ }_{23-159}$ Is Faster Compared with humPrP $\mathrm{P}_{23-144}$-In contrast to the unseeded reaction, in a seeded aggregation the speed of aggregation is additionally determined by the nature of the seed. Therefore, we investigated whether the increased aggregation propensity of hum $\operatorname{PrP}_{23-159}$ is an intrinsic property of the protein by comparing the seeding reactions of both mutants by seeding with hum $\operatorname{PrP}_{23-159}$, hum $\operatorname{PrP}_{23-144}$, and hum $\operatorname{PrP}_{106-126}$ fibrils.

Interestingly, the seeding of hum $\operatorname{PrP}_{23-159}$ with either hum $\mathrm{PrP}_{23-159}$ or hum $\operatorname{PrP}_{23-144}$ fibrils was much faster compared with seeding of hum $\operatorname{PrP}_{23-144}$ (Fig. 5) The average aggregation halftimes for seeding of hum $\mathrm{PrP}_{23-159}$ were almost identical with $4.3 \mathrm{~h}$ for seeding with hum $\operatorname{PrP}_{23-159}$ fibrils and $4.7 \mathrm{~h}$ for seeding with of hum $\operatorname{PrP}_{23-144}$. In contrast, seeding of hum $\operatorname{PrP}_{23-144}$ with both mutant fibrils was significantly different since this resulted in a pronounced biphasic aggregation kinetic (Fig. 5, $D$ and $E$ ). Furthermore, fibrils of humPrP $\operatorname{Pr}_{23-144}$ were significantly more efficient in seeding of hum $\operatorname{PrP}_{23-144}$ compared with seeding with hum $\operatorname{PrP}_{23-159}$ fibrils. The average prephase aggregation halftimes were 2.7 and $10.9 \mathrm{~h}$ for seeding with hum $\operatorname{PrP}_{23-144}$ and hum $\operatorname{PrP}_{23-159}$, whereas the average aggregation halftimes of the main phase were 10.4 and $47.8 \mathrm{~h}$, respectively. 
Prion Helix 1 Is Not Converted to $\boldsymbol{\beta}$-Sheet

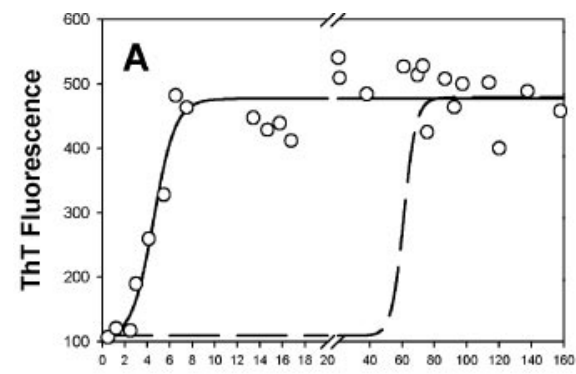

time (h)

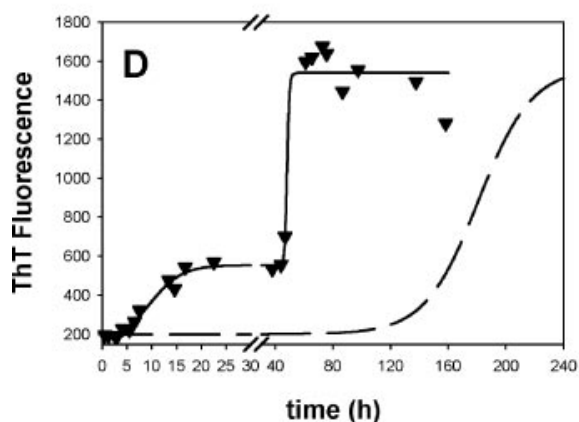

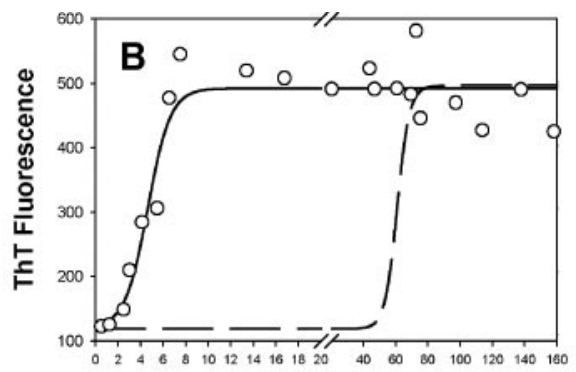

time (h)

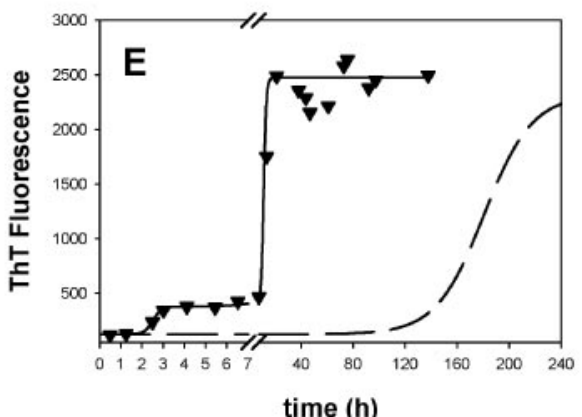

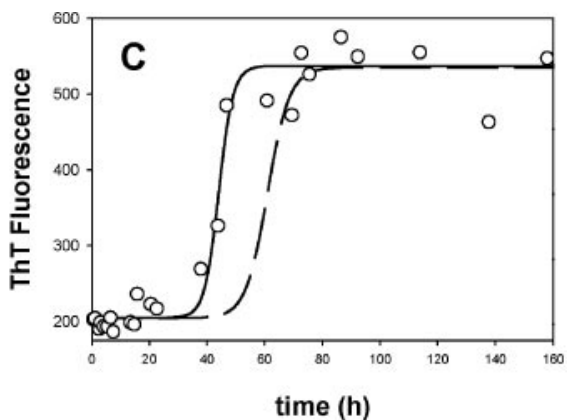

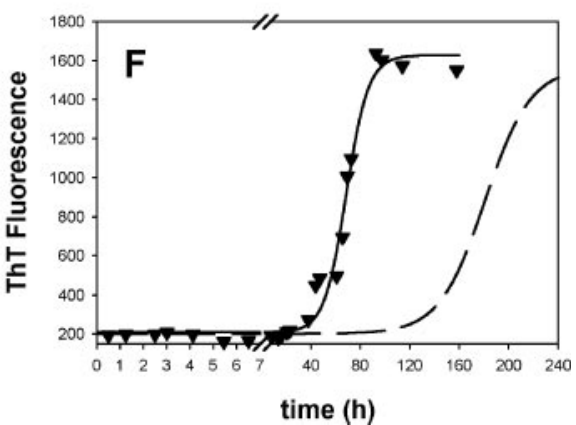

FIGURE 5. Seeded aggregation of humPrP $\mathbf{P}_{\mathbf{2 3 - 1 5 9}}$ is faster compared to humPrP $\mathbf{2 3 - 1 4 4}$. The seeding of $200 \mu \mathrm{M}$ mutant prion protein at pH $6.5 \mathrm{Was}$ followed by thioflavin $T(T h T)$ fluorescence. Both mutant prion proteins humPrP $23-159(A-C)$ and humPrP $\operatorname{Pr}_{23-144}(D-F)$ were seeded by $1 \%$ (w/w) fibrils of humPrP $23-159(A$ and $D)$, of hum $\operatorname{PrP}_{23-144}(B$ and $E)$, and humPrP $\operatorname{Pr6}_{126}(C$ and $F)$ Seeded aggregation of humPrP $\operatorname{Pr}_{23-159}(A$ and $B)$ is faster compared with humPrP $23-144(D$ and $E)$ including seeding with humPrP ${ }_{106-126}(C$ and $F)$. Solid lines represent the result for fitting of the data according to Equation 1 or 2 , whereas dashed lines correspond to the unseeded aggregation kinetics.

The difference between both mutants could further be demonstrated by seeding with hum $\operatorname{PrP}_{106-126}$ fibrils (Fig. 5, C and $F)$. To our surprise we observed a significant seeding of hum $\mathrm{PrP}_{23-144}$ which is in contrast to a previous report (13). At present the reason for this difference remains unclear, although the lower concentration of hum $\operatorname{PrP}_{23-144}$ in our experiments is more favorable for detecting any seeding effect. However, again seeding of hum $\operatorname{PrP}_{23-159}$ was faster compared with hum $\operatorname{PrP}_{23-144}$, resulting in aggregation halftimes of 42 and $71 \mathrm{~h}$. In conclusion, the results of the seeded and unseeded reactions clearly demonstrate that the higher aggregation propensity of hum $\operatorname{PrP}_{23-159}$ compared with humPrP $\mathrm{P}_{23-144}$ is an intrinsic property of the protein.

Helix1 in humPrP $23-159$ Fibrils Is Not PK-resistant-The comparison of the aggregation kinetics clearly demonstrated that helix1 is involved in the aggregation process, but the mechanism as to how it promotes aggregation remained unclear. It would be most obvious if helix1 is directly converted into a protease-resistant $\beta$-sheet on aggregation. To examine this, prion aggregates of both mutants were subjected to digestion with PK and analyzed by SDS-PAGE. Due to significant smearing with classical SDS-PAGE we used an alternative SDS-PAGE system, which was demonstrated to separate the also aggregation-prone $\mathrm{A} \beta$ peptides differing by only one amino acid in size (28). Fibrils of both mutants were quite resistant to concentrations as high as $100 \mu \mathrm{g} / \mathrm{ml}$ PK for $1 \mathrm{~h}$ (Fig. 6A). The apparent size of $7 \mathrm{kDa}$ for the PK-resistant fragment of the Y145Stop mutant fibrils is identical to that reported earlier (29). The increased apparent size of $8 \mathrm{kDa}$ for the PK-resistant fragment of hum $\operatorname{PrP}_{23-159}$ fibrils (Fig. 6A) suggested either N- or C-terminal extension of the 160Stop fragment compared with the Y145Stop mutant. This difference may result from different known N-terminal cleavage sites of human $\operatorname{PrP}^{\mathrm{Sc}}$ at residue 82 (type 1) and 97 (type 2) (30). Western blot analysis using antibody 3B5, which recognizes the type 1 cleavage pattern, was negative for the PK-resistant fragments (data not shown), whereas the 1E4 antibody directed against amino acids 98-109 (Fig. 6E) recognized PK-resistant fragments of both mutants (Fig. 6C), suggesting, rather, a type 2 cleavage pattern. Indeed, Edman sequencing of both PK-resistant cores resulted in cleavage sites at amino acids 97 and 98 (Fig. 6B), which corresponds exactly to the cleavage pattern type 2 (30). This suggested that the PK-resistant fragment of hum $\mathrm{PrP}_{23-159}$ is C-terminal-extended by the helix1. However, in contrast to the soluble isoform, none of the helix1 antibodies 6H4 (Fig. 6D) and 12F10 (data not shown) recognized the PK-resistant fragments of humPrP $23-159$ fibrils.

Thus, helix1 appears not to be converted into PK-resistant $\beta$-sheet in hum $\mathrm{PrP}_{23-159}$ fibrils. The observed size difference of the PK-resistant fragments is probably due to C-terminal extension of the hum $\operatorname{PrP}_{23-159}$ fragment by a few amino acids since, as mentioned above, the used SDS-PAGE system is able to separate $\mathrm{A} \beta$-peptides differing only by one amino acid in size (28).

Helix1 Is Not Converted to $\beta$-Sheet-To further confirm that helix1 is not converted into $\beta$-sheet, we analyzed the aggregates by FTIR. If helix1 from amino acid 144-156 (31) is completely converted, there should be an increase of $9.5 \%$ in the $\beta$-sheet fraction in aggregates from hum $\mathrm{PrP}_{23-159}$ compared with humPrP $23-144$.

Curve fitting analysis (Fig. 7) resulted in average peak wave numbers of $1627,1640,1652$, and $1664 \mathrm{~cm}^{-1}$, almost identical to that observed previously for humPrP $\mathrm{P}_{23-144}$ (13). It was 
A

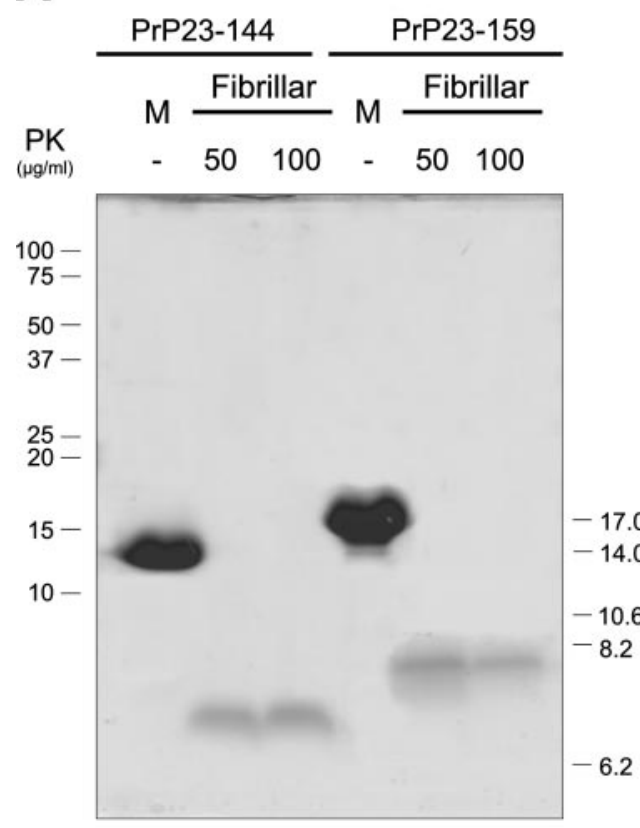

B

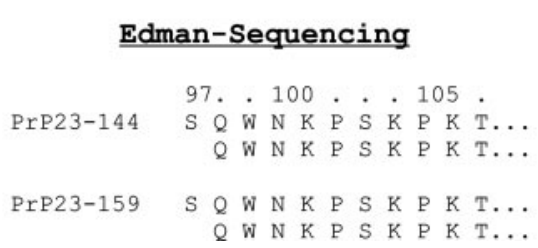

C

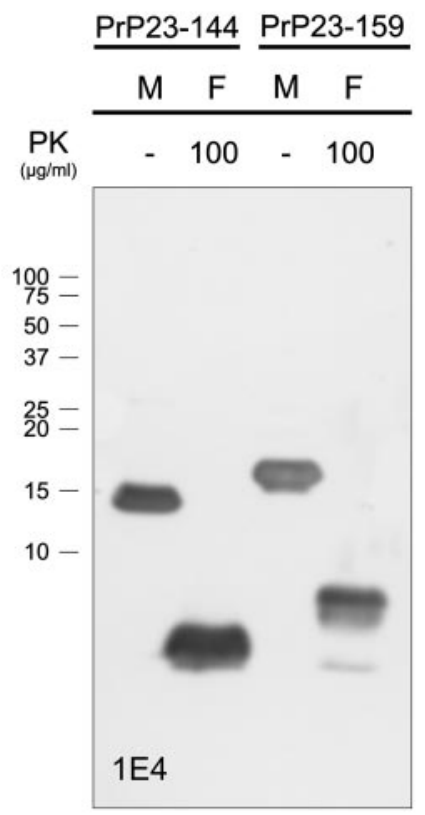

D

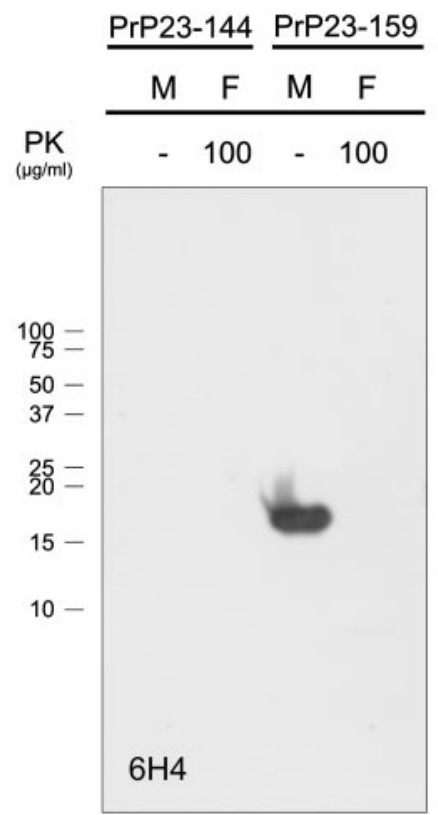

$\mathbf{E}$

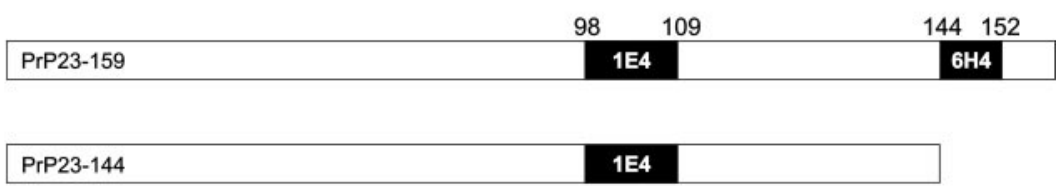

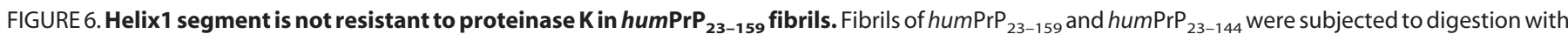
proteinase K. A, SDS-PAGE analysis of digested fibrils according to Wiltfang et al. (28) This SDS-PAGE system was demonstrated to separate A $\beta$ peptides differing only by one amino acid (28). B, Edman sequencing of the PK-resistant fragments revealed identical $\mathrm{N}$-terminal sequences. C, Western blot analysis using antibody $1 \mathrm{E} 4$ confirms the proteinase $\mathrm{K}$ cleavage pattern 2 of both fibrils. $D$, Western blot analysis demonstrate that the helix 1 is not resistant to digestion with proteinase $\mathrm{K}$ since neither antibody $6 \mathrm{H} 4$ nor $12 \mathrm{~F} 10$ (data not shown) recognize digested humPrP ${ }_{23-159}$ fibrils $(F$ ), in contrast to the undigested monomeric isoform $(M) . E$, in contrast to the antibody $1 \mathrm{E} 4$, the $6 \mathrm{H} 4$ antibody is only able to recognize humPrP ${ }_{23-159}$ due to the location of epitopes schematically depicted for both mutants.

recently demonstrated that amide I' peaks in the range 1611$1630 \mathrm{~cm}^{-1}$ are characteristic for $\beta$-sheet formed by amyloid fibrils, whereas native $\beta$-sheet clustered from 1630 to 1643 $\mathrm{cm}^{-1}$ (32). Therefore, the peaks at 1615 and $1627 \mathrm{~cm}^{-1}$ were assigned to amyloid $\beta$-sheet and $\beta$-sheet, respectively. The observed maximum at $1640 \mathrm{~cm}^{-1}$ is very close to the classical random coil amide I' at $1643 \mathrm{~cm}^{-1}$. The amide I' peak at 1652 $\mathrm{cm}^{-1}$ corresponded to classical $\alpha$-helix at $1650 \mathrm{~cm}^{-1}$ in $\mathrm{D}_{2} \mathrm{O}$. However, the formation of classical $\alpha$-helix on aggregation appeared rather unlikely. Because the non-protease-resistant $\mathrm{N}$-terminal segment from amino acids 23-98 comprises more than $50 \%$ of both stop mutant molecules, this helix-like peak was attributed to the $\mathrm{N}$-terminal segment. The sum of both peak areas at 1640 and $1652 \mathrm{~cm}^{-1}$, therefore, results in values of 40 and $46 \%$, respectively (Table 1 ). At present the reason for the appearance of the helix like peak at $1652 \mathrm{~cm}^{-1}$ is unclear. Finally, the frequencies at 1664 and $1675 \mathrm{~cm}^{-1}$ are characteristic for turns and loops (33), whereas $1684 \mathrm{~cm}^{-1}$ was assigned to the high frequency component of $\beta$-sheet.

Seeding of the Q160Stop mutant has no significant effect on secondary structural changes compared with the unseeded aggregates except for seeding with Y145Stop (Fig. $7 B$ ), where the fraction of $\beta$-sheet at $1627 \mathrm{~cm}^{-1}$ is increased by $4 \%$ (Table
1). In contrast, seeding of Y145Stop with itself and Q160Stop significantly reduced random coil fractions compared with unseeded aggregates (Table 1). Furthermore, seeding with Y145Stop led to an increase of almost $6 \%$ for amyloid $\beta$-sheet at $1615 \mathrm{~cm}^{-1}$. Interestingly, curve-fitting for seeding of Y145Stop with hum $\operatorname{PrP}_{106-126}$ resulted in only one amyloid $\beta$-sheet peak located at $1620 \mathrm{~cm}^{-1}$ (Fig. $7 F$ ). This corresponds exactly to the amyloid $\beta$-sheet wave number observed in $\operatorname{PrP}_{106-126}$ aggregates (13). Thus, in contrast to seeding of hum $\operatorname{PrP}_{23-159}$, fibrils of hum $\mathrm{PrP}_{106-126}$ are able to transmit their structural properties to hum $\mathrm{PrP}_{23-144}$ on seeding.

The most interesting question was whether the C-terminal extension, including helix 1 , is converted into $\beta$-sheet. Theoretically, complete conversion of this extension (amino acids 145159 ) into $\beta$-sheet should result in an increase of up to $11 \%$ in $\beta$-sheet compared with the Y145Stop mutant. Considering only the unseeded reactions, we obtained $24.1 \%$ pure random coil, $21.8 \%$ helix-like structure, and $30.7 \% \beta$-sheet for the Q160Stop mutant (Table 1). For Y145Stop, we obtained 21.4\% pure random coil, $20.5 \%$ helix-like structure, and $34.7 \% \beta$-sheet (Table 1). However, we had to take into consideration that Q160Stop mutant is longer by 15 amino acids. Thus, the percentages of Y145Stop were corrected by multiplying with 0.89 , 

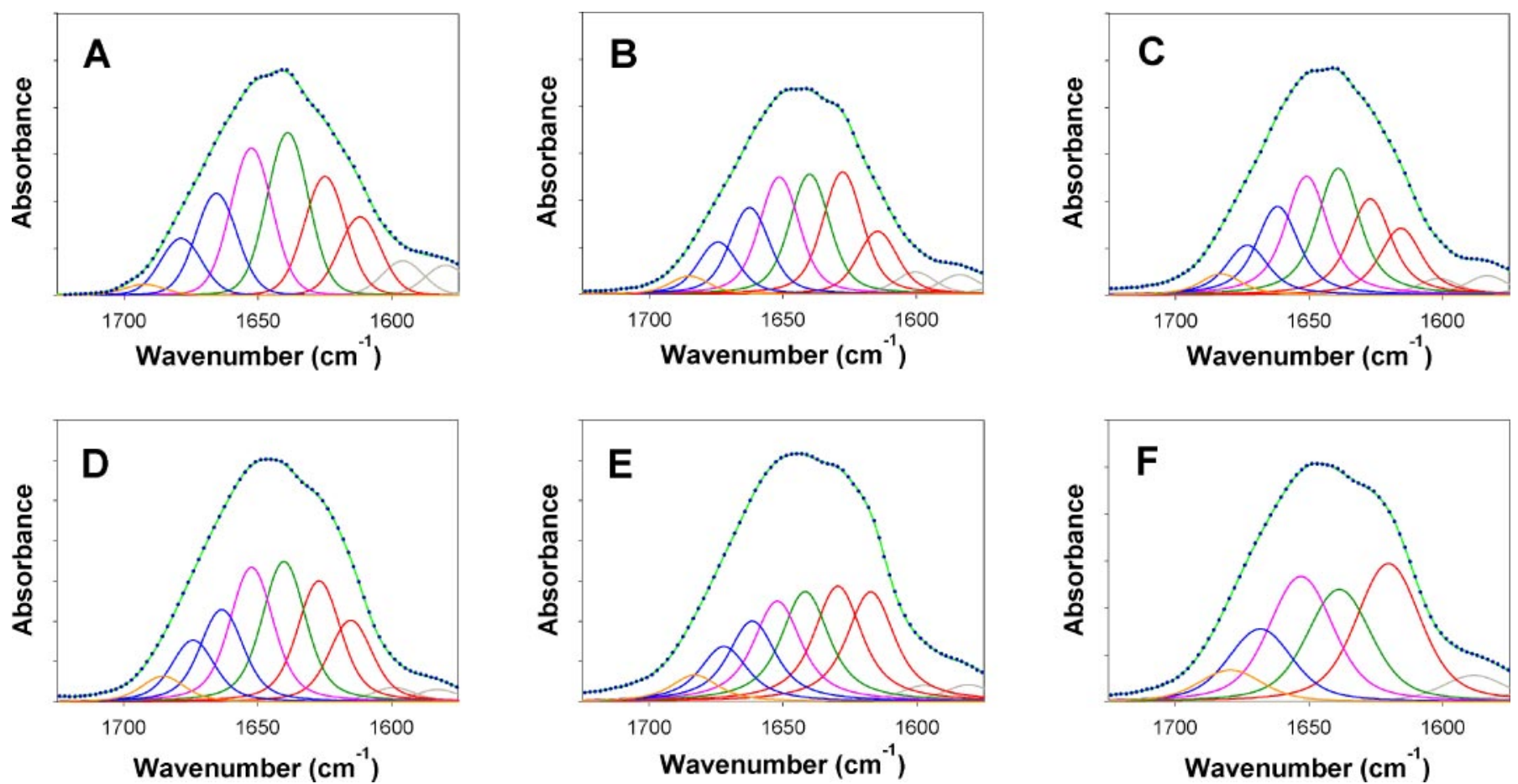

FIGURE 7. Helix 1 is not converted to $\boldsymbol{\beta}$-sheet. FTIR spectroscopic analysis of fibrillar humPrP $\operatorname{Pr}_{23-159}(A-C)$ and humPrP $\operatorname{Pr}_{23-144}(D-F)$ for the amide $I^{\prime}$ region in $D_{2} O$ to determine their secondary structure content by peak fitting (Table 1$)$. In contrast to the unseeded reactions $(A$ and $C$ ) in seeded reactions $(B, C, E$, and $F) 1 \%$ $(\mathrm{w} / \mathrm{w})$ fibrillar humPrP ${ }_{23-144}(B$ and $E)$ and fibrillar humPrP $106-126(C$ and $F)$ was added. The results of the peak fitting analysis of the FTIR spectra (closed circles) are shown as lines (green). $\beta$-Sheet (red) is assigned to peaks at 1615 and $1627 \mathrm{~cm}^{-1}$. The peaks at $1640 \mathrm{~cm}^{-1}$ corresponds to random coil (dark green), and helix-like structure (pink) at $1652 \mathrm{~cm}^{-1}$ is attributed to the $\mathrm{N}$-terminal segment. The blue peaks at 1664 and $1675 \mathrm{~cm}^{-1}$ are assigned to loops and turns, whereas $1684 \mathrm{~cm}^{-1}$ was assigned to the high frequency component of $\beta$-sheet (orange peaks). Gray peaks represent contributions due to amino acid side chains.

TABLE 1

Quantitative analysis for FTIR spectra of prion aggregates

\begin{tabular}{|c|c|c|c|c|c|}
\hline \multirow{3}{*}{ Secondary structure assignment } & \multirow{3}{*}{ Wave number } & \multicolumn{4}{|c|}{ Percentage of secondary structure element } \\
\hline & & \multirow{2}{*}{ Unseeded } & \multicolumn{3}{|c|}{ Seeding } \\
\hline & & & $\operatorname{PrP}_{23-159}$ & $\operatorname{PrP}_{23-144}$ & $\operatorname{PrP}_{106-126}$ \\
\hline \multirow{2}{*}{\multicolumn{6}{|c|}{ humPrP $23-159$}} \\
\hline & & & & & \\
\hline Amyloid $\beta$-sheet & 1615 & 11.6 & 11.8 & 10.8 & 11.7 \\
\hline$\beta$-Sheet & 1627 & 17.5 & 17.1 & 21.1 & 17.0 \\
\hline Random & 1640 & 24.1 & 22.4 & 20.7 & 22.4 \\
\hline$\alpha$-Helix ${ }^{a}$ & 1652 & 21.8 & 21.1 & 20.3 & 20.9 \\
\hline Turn/loop & 1664 & 15.1 & 15.6 & 15.0 & 15.6 \\
\hline Turn/loop & 1675 & 8.4 & 9.0 & 9.0 & 8.7 \\
\hline Amyloid $\beta$-sheet & 1684 & 1.6 & 3.2 & 3.1 & 3.7 \\
\hline \multicolumn{6}{|l|}{ humPrP $\mathrm{P}_{23-144}$} \\
\hline Amyloid $\beta$-sheet & 1615 & 12.4 & 13.1 & 18.1 & $28.8\left(1620 \mathrm{~cm}^{-1}\right)$ \\
\hline$\beta$-Sheet & 1627 & 18.4 & 19.0 & 19.1 & \\
\hline Random & 1640 & 21.4 & 20.0 & 17.9 & 23.4 \\
\hline$\alpha$-Helix ${ }^{a}$ & 1652 & 20.5 & 16.4 & 16.7 & 26.1 \\
\hline Turn/loop & 1664 & 14.0 & 16.7 & 14.1 & 15.1 \\
\hline Turn/loop & 1675 & 9.4 & 10.7 & 9.5 & \\
\hline Amyloid $\beta$-sheet & 1684 & 3.9 & 4.0 & 4.5 & 6.5 \\
\hline
\end{tabular}

${ }^{a}$ This helix-like structure is mainly attributed to the N-terminal segment.

resulting in $19.1 \%$ pure random coil, $18.2 \%$ helix-like structure, and $30.9 \% \beta$-sheet. There is almost no difference in total $\beta$-sheet since $\beta$-sheet of hum $\operatorname{PrP}_{23-144}$ is only $0.2 \%$ higher compared with hum $\operatorname{PrP}_{23-159}$ fibrils. However, there is an increase of $3.6 \%$ in $\alpha$-helix like structure in hum $\operatorname{PrP}_{23-159}$ fibrils, which suggests that some $\alpha$-helix could be present. Finally, random coil was increased by $5.0 \%$. Taken together, there is no significant difference in $\beta$-sheet but $8.6 \%$ of the possible $11 \%$ secondary structure, corresponding to the fraction of the $\mathrm{C}$-terminal extension in hum $\operatorname{PrP}_{23-159}$ compared with hum $\operatorname{PrP}_{23-144}$, is due to random coil or helix. This together with the data from proteinase $\mathrm{K}$ digestion clearly indicates that helix1 is not converted into $\beta$-sheet.

\section{DISCUSSION}

The aggregation-promoting effect of the highly charged helix1 in hum $\operatorname{PrP}_{23-159}$ relative to humPrP $\mathrm{P}_{23-144}$ is surprising since, in general, truncation of non-amyloidogenic regions in 
proteins prone to aggregation promotes their aggregation. Calculation of the aggregation tendency using Zygreggator (34) resulted in a significant lower aggregation propensity for $\operatorname{PrP}_{95-159}$ (Zagg $\left.=-0.80\right)$ compared with PrP95-144 (Zagg = -0.18 ). Normally charged amino acids are even added to peptides to increase their solubility, thereby preventing their aggregation. Interestingly, the increased aggregation propensity of hum $\operatorname{PrP}_{23-159}$ compared with hum $\operatorname{PrP}_{23-144}$ correlates also in vivo with the 6-year earlier onset of clinical symptoms in one patient with a prion Q160Stop mutation (35) compared with the Y145Stop mutation (29).

Our results clearly demonstrate that helix 1 is involved in the aggregation of hum $\operatorname{PrP}_{23-159}$. However, at present the unusual nature of this aggregation-promoting effect is unclear, although it was speculated that helix1 might form intermolecular salt bridges on aggregation of the prion protein (36).

Although hum $\operatorname{PrP}_{23-159}$ aggregated significantly faster compared with hum $\operatorname{PrP}_{23-144}$, both PK-digestion and FTIR analysis clearly demonstrate that helix 1 is not converted into $\beta$-sheet. Thus, we provide here for the first time strong direct evidence that helix 1 in $\operatorname{PrP}^{\mathrm{Sc}}$ is not converted into $\beta$-sheet. This is confirmed by the fact that both $\operatorname{PrP}^{\mathrm{C}}$ as well as $\operatorname{PrP}^{\mathrm{Sc}}$ can be precipitated with the antibody $6 \mathrm{H} 4$, which recognizes an epitope in helix1 (37). Antibodies directed against helix1 are even able to block the conversion from $\operatorname{PrP}^{C}$ to $\operatorname{PrP}^{\mathrm{Sc}}(38,39)$. Furthermore, the unusual high propensity for $\alpha$-helix formation of the helix 1 segment (27) and its unusual low aggregation propensity (40) are in line with our results. Helix1 was completely dispensable for the generation of infectious $\operatorname{PrP}^{\mathrm{Sc}}(41,42)$, which further supports our results.

At present neither NMR nor x-ray crystallography is able to completely resolve the three-dimensional structure of $\operatorname{Pr} \mathrm{P}^{\mathrm{Sc}}$. Therefore, evidence in the puzzle of the $\operatorname{PrP}^{\mathrm{Sc}}$ structure can only be obtained by using different biochemical approaches. We provide here strong direct evidence that in contrast to earlier assumptions $(43,17)$, helix 1 is not converted to $\beta$-sheet in $\operatorname{PrP}^{\mathrm{Sc}}$. However, our results leave the possibility that helix1 is shortened in $\operatorname{PrP}^{\mathrm{Sc}}$ since there is an increase in apparent helix content of $4 \%$ compared with maximal possible $9.5 \%$ in fibrils of hum $\operatorname{PrP}_{23-159}$ relative to hum $\operatorname{PrP}_{23-144}$. Interestingly, our data agree with results of molecular dynamic simulations for $\mathrm{pH}$ induced conformational conversion. Although helix1 experienced some loss of helix, none of the lost amino acids was involved in the formation of $\beta$-sheet (44).

Acknowledgments-We are grateful to H.-H. Belz (Thermo Electron Corp.) for assistance in FTIR measurements. We thank B. Schmidt for performing Edman sequencing and H. J. Fritz for helpful discussions.

\section{REFERENCES}

1. Legname, G., Baskakov, I. V., Nguyen, H. O., Riesner, D., Cohen, F. E., DeArmond, S. J., and Prusiner, S. B. (2004) Science 305, 673-676

2. Swietnicki, W., Petersen, R., Gambetti, P., and Surewicz, W. K. (1997) J. Biol. Chem. 272, 27517-27520

3. Hornemann, S., and Glockshuber, R. (1998) Proc. Natl. Acad. Sci. U. S. A. 95, 6010-6014

4. Swietnicki, W., Morillas, M., Chen, S. G., Gambetti, P., and Surewicz, W. K. (2000) Biochemistry 39, 424-431

\section{Prion Helix 1 Is Not Converted to $\beta$-Sheet}

5. Baskakov, I. V., Aagaard, C., Mehlhorn, I., Wille, H., Groth, D., Baldwin, M. A., Prusiner, S. B., and Cohen, F. E. (2000) Biochemistry 39, 2792-2804

6. Swietnicki, W., Petersen, R. B., Gambetti, P., and Surewicz, W. K. (1998) J. Biol. Chem. 273, 31048-31052

7. Liemann, S., and Glockshuber, R. (1999) Biochemistry 38, 3258 -3267

8. Baskakov, I. V., Legname, G., Prusiner, S. B., and Cohen, F. E. (2001) J. Biol. Chem. 276, 19687-19690

9. Apetri, A. C., and Surewicz, W. K. (2002) J. Biol. Chem. 277, $44589-44592$

10. Riek, R., Hornemann, S., Wider, G., Glockshuber, R., and Wuthrich, K. (1997) FEBS Lett. 413, 282-288

11. Peretz, D., Williamson, R. A., Matsunaga, Y., Serban, H., Pinilla, C., Bastidas, R. B., Rozenshteyn, R., James, T. L., Houghten, R. A., Cohen, F. E., Prusiner, S. B., and Burton, D. R. (1997) J. Mol. Biol. 273, 614-622

12. Vanik, D. L., Surewicz, K. A., and Surewicz, W. K. (2004) Mol. Cell 14, $139-145$

13. Kundu, B., Maiti, N. R., Jones, E. M., Surewicz, K. A., Vanik, D. L., and Surewicz, W. K. (2003) Proc. Natl. Acad. Sci. U. S. A. 100, 12069-12074

14. Jones, E. M., and Surewicz, W. K. (2005) Cell 121, 63-72

15. Pan, K. M., Baldwin, M., Nguyen, J., Gasset, M., Serban, A., Groth, D., Mehlhorn, I., Huang, Z., Fletterick, R. J., Cohen, F. E., and Prusiner, S. B. (1993) Proc. Natl. Acad. Sci. U. S. A. 90, 10962-10966

16. Riek, R., Hornemann, S., Wider, G., Billeter, M., Glockshuber, R., and Wuthrich, K. (1996) Nature 382, 180-182

17. Wille, H., Michelitsch, M. D., Guenebaut, V., Supattapone, S., Serban, A., Cohen, F. E., Agard, D. A., and Prusiner, S. B. (2002) Proc. Natl. Acad. Sci. U. S. A. 99, 3563-3568

18. Kramer, M. L., Kratzin, H. D., Schmidt, B., Romer, A., Windl, O., Liemann, S., Hornemann, S., and Kretzschmar, H. (2001) J. Biol. Chem. 276, 16711-16719

19. Wiltfang, J., Arold, N., and Neuhoff, V. (1991) Electrophoresis 12, 352-366

20. Delaglio, F., Grzesiek, S., Vuister, G. W., Zhu, G., Pfeifer, J., and Bax, A. (1995) J. Biomol. NMR 6, 277-293

21. Bax, A., and Grzesiek, S. (1993) Acc. Chem. Res. 26, 131-138

22. Schwarzinger, S., Kroon, G. J. A., Foss, T. R., Chung, J., Wright, P. E., and Dyson, H. J. (2001) J. Am. Chem. Soc. 123, $2970-2978$

23. Wishart, D. S., and Sykes, B. D. (1994) Methods Enzymol. 239, 363-392

24. Heegaard, N. H., Roepstorff, P., Melberg, S. G., and Nissen, M. H. (2002) J. Biol. Chem. 277, 11184-11189

25. Morillas, M., Swietnicki, W., Gambetti, P., and Surewicz, W. K. (1999) J. Biol. Chem. 274, 36859-36865

26. Dyson, H. J., and Wright, P. E. (1998) Nat. Struct. Biol. 5, (suppl.) 499-503

27. Ziegler, J., Sticht, H., Marx, U. C., Muller, W., Rosch, P., and Schwarzinger, S. (2003) J. Biol. Chem. 278, 50175-50181

28. Wiltfang, J., Esselmann, H., Cupers, P., Neumann, M., Kretzschmar, H., Beyermann, M., Schleuder, D., Jahn, H., Ruther, E., Kornhuber, J., Annaert, W., De Strooper, B., and Saftig, P. (2001) J. Biol. Chem. 276, $42645-42657$

29. Ghetti, B., Piccardo, P., Spillantini, M. G., Ichimiya, Y., Porro, M., Perini, F., Kitamoto, T., Tateishi, J., Seiler, C., Frangione, B., Bugiani, O., Giaccone, G., Prelli, F., Goedert, M., Dlouhy, S. R., and Tagliavini, F. (1996) Proc. Natl. Acad. Sci. U. S. A. 93, 744-748

30. Parchi, P., Zou, W., Wang, W., Brown, P., Capellari, S., Ghetti, B., Kopp, N., Schulz-Schaeffer, W. J., Kretzschmar, H. A., Head, M. W., Ironside, J. W., Gambetti, P., and Chen, S. G. (2000) Proc. Natl. Acad. Sci. U. S. A. 97, $10168-10172$

31. Calzolai, L., and Zahn, R. (2003) J. Biol. Chem. 278, 35592-35596

32. Zandomeneghi, G., Krebs, M. R., McCammon, M. G., and Fandrich, M. (2004) Protein Sci. 13, 3314-3321

33. Bocharova, O. V., Breydo, L., Salnikov, V. V., and Baskakov, I. V. (2005) Biochemistry 44, 6776-6787

34. Pawar, A. P., Dubay, K. F., Zurdo, J., Chiti, F., Vendruscolo, M., and Dobson, C. M. (2005) J. Mol. Biol. 350, 379-392

35. Finckh, U., Muller-Thomsen, T., Mann, U., Eggers, C., Marksteiner, J., Meins, W., Binetti, G., Alberici, A., Hock, C., Nitsch, R. M., and Gal, A. (2000) Am. J. Hum. Genet. 66, 110-117 
Prion Helix 1 Is Not Converted to $\boldsymbol{\beta}$-Sheet

36. Morrissey, M. P., and Shakhnovich, E. I. (1999) Proc. Natl. Acad. Sci. U. S. A. 96, 11293-11298

37. Paramithiotis, E., Pinard, M., Lawton, T., LaBoissiere, S., Leathers, V. L., Zou, W. Q., Estey, L. A., Lamontagne, J., Lehto, M. T., Kondejewski, L. H., Francoeur, G. P., Papadopoulos, M., Haghighat, A., Spatz, S. J., Head, M., Will, R., Ironside, J., O’Rourke, K., Tonelli, Q., Ledebur, H. C., Chakrabartty, A., and Cashman, N. R. (2003) Nat. Med. 9, 893-899

38. Heppner, F. L., Musahl, C., Arrighi, I., Klein, M. A., Rulicke, T., Oesch, B., Zinkernagel, R. M., Kalinke, U., and Aguzzi, A. (2001) Science 294, $178-182$

39. Enari, M., Flechsig, E., and Weissmann, C. (2001) Proc. Natl. Acad. Sci.
U. S. A. 98, 9295-9299

40. Sharman, G. J., Kenward, N., Williams, H. E., Landon, M., Mayer, R. J., and Searle, M. S. (1998) Fold. Des. 3, 313-320

41. Muramoto, T., Scott, M., Cohen, F. E., and Prusiner, S. B. (1996) Proc. Natl. Acad. Sci. U. S. A. 93, 15457-15462

42. Supattapone, S., Bosque, P., Muramoto, T., Wille, H., Aagaard, C., Peretz, D., Nguyen, H. O., Heinrich, C., Torchia, M., Safar, J., Cohen, F. E., DeArmond, S. J., Prusiner, S. B., and Scott, M. (1999) Cell 96, 869-878

43. Huang, Z., Prusiner, S. B., and Cohen, F. E. (1995) Fold. Des. 1, 13-19

44. Alonso, D. O., DeArmond, S. J., Cohen, F. E., and Daggett, V. (2001) Proc. Natl. Acad. Sci. U. S. A. 98, 2985-2989 